\title{
From Micro to Macro
}

Citation for published version (APA):

Kaltenberg, M. A. (2020). From Micro to Macro: essays on technological change and income divergence. [Doctoral Thesis, Maastricht University]. ProefschriftMaken. https://doi.org/10.26481/dis.20200318mak

\section{Document status and date:}

Published: 01/01/2020

DOI:

10.26481/dis.20200318mak

Document Version:

Publisher's PDF, also known as Version of record

\section{Please check the document version of this publication:}

- A submitted manuscript is the version of the article upon submission and before peer-review. There can be important differences between the submitted version and the official published version of record.

People interested in the research are advised to contact the author for the final version of the publication, or visit the DOI to the publisher's website.

- The final author version and the galley proof are versions of the publication after peer review.

- The final published version features the final layout of the paper including the volume, issue and page numbers.

Link to publication

\footnotetext{
General rights rights.

- You may freely distribute the URL identifying the publication in the public portal. please follow below link for the End User Agreement:

www.umlib.nl/taverne-license

Take down policy

If you believe that this document breaches copyright please contact us at:

repository@maastrichtuniversity.nl

providing details and we will investigate your claim.
}

Copyright and moral rights for the publications made accessible in the public portal are retained by the authors and/or other copyright owners and it is a condition of accessing publications that users recognise and abide by the legal requirements associated with these

- Users may download and print one copy of any publication from the public portal for the purpose of private study or research.

- You may not further distribute the material or use it for any profit-making activity or commercial gain

If the publication is distributed under the terms of Article $25 \mathrm{fa}$ of the Dutch Copyright Act, indicated by the "Taverne" license above, 


\section{Abstract}

Recently, there is a growing concern about the relationship between technological change and income inequality. This thesis investigates the nature of this relationship between individuals, industries and nations using a breadth of data sources. The benefits or concerns of the impact of technological change on income depends on the perspective of analysis. Within many European countries, the main driver of rising inequality is due to automation, and this effect is caused by the fast-changing composition of the workforce. While, at the industry level, one factor that is important in explaining wage differences between industries is knowledge diversity - individuals who work in knowledge diverse industries tend to earn more, and it is especially true for occupations that have more social and interpersonal skills. At the national level, technological capabilities has a positive effect on explaining economic growth rates, particularly for lower income countries. Technological change can have positive and unintended negative effects, and understanding the context in which technological change benefits or harms can help guide policy makers. 